\title{
The wrestling with a pig in the mud metaphor in the service of liberal ideology: a critical analysis
}

Metaphor to a politician is what sex appeal is to an individual: a covert way of sending out messages of desirability Jonathan Charteris-Black

\begin{abstract}
Metaphors are used in political discourse in order to advance one particular view of the world whilst delegitimising other ideologies and belittling political opponents. The author verifies this claim by analysing the wrestling with a pig in the mud metaphor in light of the Critical Metaphor Analysis model and by providing broad reference to the socio-political context of the 2019 European Parliament election in Poland. Consistent with the premises of the selected paradigm, the investigation is performed at three intermingling levels. Basic categories of source domains present in the complex metaphorical structure are identified at the descriptive level. At the interpretative level, attention is directed towards mapping out correspondences between source and target domains. Finally, at the motivational level, the author identifies the ideological message and political intentions embedded in the metaphor's use.
\end{abstract}

Keywords: conceptual metaphor, political discourse, Critical Discourse Analysis, Critical Metaphor Analysis.

\section{Introduction}

Cognitive science has demonstrated that to a large degree we think and communicate by means of metaphors. This view of metaphor has now been around for almost forty years, if we take the 1980 publication of Lakoff \& Johnson's Metaphors We Live By as a sort of milestone. Due to the methodological developments of the framework referred to as the Conceptual Metaphor Theory (CMT), concepts such as source and target domains,

1 Address for correspondence: Department of Linguistics, University of Białystok, Pl. NZS 1, 15-420 Białystok, Poland. E-mail: k.pawlowska@uwb.edu.pl 
mappings, entailments, invariance, topology, inference and so forth, have become familiar vocabulary for analysing not only linguistic, but other conceptual phenomena. The universality of metaphorical conceptualisation suggests that metaphor should not be seen merely as a source of knotty puzzles for readers, but rather as an enlightening and helpful carrier of meaning. Steen (2004: 1298) observes that metaphorical language may be argued to simultaneously perform linguistic, conceptual, and communicative functions in discourse. "The transition of metaphor from language to thought in the old contemporary theory is being followed today by another transition, from metaphor in thought to metaphor in language, thought, and communication" (Steen 2011: 43). The researcher proposes a three-dimensional model for metaphor, in which "linguistic, conceptual, and communicative properties of metaphor are examined as relatively independent and interacting aspects that may affect all kinds of processes in production, reception, interaction, acquisition, learning, maintenance, and so on" (Steen 2011: 43).

Metaphors are highly persistent in contemporary discourse, especially in so-called mediated discourse in which they function as fundamental persuasive devices. Political actors communicate with their voters as well as with their opponents for the most part through the mass media. It is in the media and through the media that metaphors are produced, continually distributed and entrenched. Furthermore, it is argued that these mediated metaphors conform to particular frames which are privileged over and above other frames, thereby shaping our understanding of politics. Political rhetoric cannot be reduced to metaphor alone as it is just one among many rhetorical tools used for the purpose of persuasion. However, metaphor remains important because metaphorical phrases very often become the core of argumentation.

Remarkably, the general intention of this study is to redress the air of neglect surrounding the perlocutionary potential of the complex cognitive phenomenon referred to as conceptual metaphor used in political persuasion. Though the effects of metaphorical framing are studied from various perspectives and by making use of diverse methods, the central hypothesis that metaphorical frames influence people's political views and decisions has gained widespread acceptance in scientific circles (e.g., Charteris-Black 2004, 2005; Kövecses 2006; Lakoff 2009; Mio 1997; Musolff 2004, 2010, 2014; Perrez et al. 2019). Consistent with the basic premise that metaphors are discursive devices used to "create social reality and guide social action" (Lakoff \& Johnson 1980: 156), this paper in part investigates the possibilities of combining two frameworks: Critical Discourse Analysis (CDA) and Conceptual Metaphor Theory (CMT). It is argued from a critical realist perspective that these methodologies pose different, yet complementary questions about the nature of conceptualisation and political discourse. CDA scholars methodically scrutinise the interdependence between language and social structure - real-world changes, both actual or hypothetical, are examined as an outcome of communicated linguistic impact. Drawing upon the premises of critical 
thought as well as pragmatics, the Critical Metaphor Analysis (introduced by CharterisBlack 2004) aims at reducing the methodological disparity between critical analysis and cognitive linguistics. The integrated study framework provides a dual lens which can be applied to explore qualitative data, simultaneously interpreted both as mental phenomenon and discursive practice. Actually, the premises of CMT and CDA may profitably inform each other. Essentially, the Lakoffean-Johnsonian proposal opens up the possibility of tracing not only the bodily but also the cultural, historical and contextual patterns to an underlying set of metaphors.

\section{Critical analysis of mediated political discourse}

The term 'discourse' is wide enough to encompass all aspects that critical scientists aim to analyse as it includes "all forms of spoken interaction, formal and informal, and written texts of all kinds" (Potter \& Wetherell 1987: 7). Such an extensive spectrum of relevance results in an enormously large number of definitions proposed by various scholars. One of the first who substantially contributed to this issue was Michael Foucault. The French philosopher defines discourse as "an entity of sequences, of signs, in that they are enouncements (énoncés), statements in conversation” (Foucault 1969: 233).

More contemporary scientists emphasise contextual and cognitive aspects of discourse. For instance, Tyson characterises discourse as "a social language created by particular cultural conditions at a particular time and place" that expresses "a particular way of understanding human experience" (Tyson 1999: 281). Van Dijk, who analyses discourse from a socio-psychological perspective, defines it as "a communicative event, including conversational interaction, written text, as well as associated gestures, facework, typographical layout, images, and any other semiotic or multimedia dimension of signification” (van Dijk 2001: 98). Consider van Dijk's assertion (1988: 1-2): “Developments in the study of discourse in such diverse disciplines as speech communication, cognitive psychology, social psychology, microsociology, and ethnography have shown that discourse is not simply an isolated textual or dialogical structure.”

Essentially, discourse is influenced by a plethora of diverse factors and realised in different forms that might be impossible to spot individually. In his article "Multimodality", van Leeuwen states that discourse "is almost always multimodal" (van Leeuwen 2015: 447), which means that "different semiotic modes (...) are combined and integrated in a given instance of discourse or kind of discourse" (van Leeuwen 2015: 447). ${ }^{2}$ As a consequence, discourse analysis should not be limited to an explicit account of structures per se. Still, though other modes, for instance images, may function as

2 Kress \& van Leuveen, the leading researchers in the field of multimodal studies, define multimodality as "the idea that communication and representation always draw on a multiplicity of semiotic modes of which language may be one" (2001: 67-68). 
rhetorical devices, the multimodal approach in CDA does not suggest that the importance of verbal communication is being downplayed. On the contrary, it is principally language that performs the function of persuading the audience and arousing their emotional response, and for this reason critical discourse analysts predominantly concentrate on verbal forms of discourse.

Consistent with the theoretical standpoint adopted in this paper, let me base this analysis on the definition proposed by Bischoping \& Gazso, who view discourse as "a web of meanings, ideas, interactions and practices that are expressed or represented in texts (spoken and written language, gesture, and visual imagery), within institutional and everyday settings" (2016: 235). Since this paper is about the relationship between language, cognition and politics, let me focus on the type of interaction that has a sort of social dimension, namely political discourse, understood here as "the institutionally bound text and talk of politicians (...) produced in institutional settings" (van Dijk 1997: 20). Van Dijk emphasises that to count discourse as political, it should be 'done' by politicians in professional contexts: "In a more action-oriented way, we may also say that discourse is political when it accomplishes a political act in a political institution, such as governing, legislation, electoral campaigning, and so on” (van Dijk 1997: 20).

It is important to note that although van Dijk admits that politicians as authors of political discourse and other political practices are crucial in political science, they are not the only participants in the domain of politics. Thus, from the interactional perspective, it should also include other recipients in political communicative events such as the public, the people, citizens, the 'masses', and other groups or categories (van Dijk 1997). ${ }^{3}$

An important part of the political system is communication of information and mass media play a central role in this process. Media culture is still extending and developing its forms from more traditional such as newspapers, magazines, cinema, video, radio and terrestrial television to more advanced, using Coxall et al.'s terminology 'globalized' means, which include multi-channel satellite, cable and digital television, the Internet and other embryonic modes such as mass texting (Coxall et al. 2003: 156). Coxall et al. (2003: 156) observe that one of their major roles is to provide "the potential for (a) person to link up with other like-minded individuals anywhere in the world to create a 'virtual' organisation through which they can pursue political goals.” Taking a constructionist attitude, Cottle argues that "[media] representations do not so much 'distort' reality as productively provide the means by which 'reality' is actively constructed and/or known" (Cottle 2000: 10). Van Gorp (2007) provides a detailed account of how cultural frames embedded in media content (either deliberately or unwittingly) which interact with the 3 In this respect see Wilson (2015), who refers to studies (e.g., Liebes \& Ribak 1991), whose authors argue
that family talk about political events could also be considered political discourse. 
mental schemata of individual readers or receivers, work as a bridging device between cognition and culture and thus are a fundamental part of the dynamic process whereby social reality is (re)produced, shaped and transformed. These ways of knowing and believing form the basis of the everyday, common sense ideologies which for many people are the underlying foundations of 'truths' about the social world they live in and the value system that should guide behaviour in it (van Dijk 1998).

Nevertheless, shaping the mental models of the recipients is not the objective per $s e$ - it would be meaningless if done for the sake of just doing so. From the point of view of the social actor who is engaged in such a process, it is invaluable because it may also influence future actions of the addressees. Van Dijk observes that mass media will generally focus on 'facts' that are consistent with elite political interests (1998: 184). Subjects that are indeed in control of a broad range of public discourses and social events are what van Dijk defines as elite institutions. Van Dijk puts it in the following words: "in modern societies, discourse access is a primary condition for the manufacture of consent, and therefore the most effective way to exercise power and dominance" (van Dijk 1996: 102). However, van Dijk stresses that sole access does not guarantee any influence over the recipients, as there are diverse forms of resistance (1995: 13): "Special access to the minds of the public does not imply control (...) Rejection, disbelief, criticism, or other forms of resistance or challenge may be involved and thus signal modes of counterpower."

Essentially, political rhetoric is an outstanding discipline that is best-suited to go hand in hand with its counterpart, namely critical thinking - the skill that enables us to peel back the formulas, thus revealing the content of arguments resistant to manipulations, delusions, and deceptions. Critical Discourse Analysis, which has now become one of the most extensively used discourse analysis paradigms, is the model which primarily aims at uniting linguistic analysis and ideological critique. It absorbs the research achievements of many other disciplines such as psychology, sociology, ethnology, mass media, etc. The leading figures in the field are Fairclough, Hodge, Kress, Wodak, van Dijk, van Leeuwen.

Critical approach primarily assumes a dialectical relationship between language and other social elements. For instance, Fairclough explains his view of this unitary system in the following manner: “(...) language connects with the social through being the primary domain of ideology, and through being a site of, and a stake in, struggles of power" (1989: 14-15). ${ }^{4}$ Most important in Fairclough's model $(1989,1995)$ is the correlation between text, interpretation, and context. The researcher distinguishes clearly-defined steps (or stages) along with the three dimensions of discourse when conducting studies

4 Fairclough's $(1995,2001)$ analytical model is composed of some critical social theories, such as Foucault's concept of orders of discourse, Gramsci's theory of hegemony, and Habermas' colonization of discourse, etc. 
with the theory of CDA: the description stage, the interpretation stage, and the explanation stage - the general model adopted by the Critical Metaphor Analysis scholars.

Habitually, CDA viewed metaphor as an element of micro-level analysis. ${ }^{5}$ It is probably due to the findings of cognitive science which recently resulted in the fact that this complex issue has received appropriate attention and is no longer treated as just a rhetoric trope, but is viewed as "central to CDA since it deals with forming a coherent view of reality" (Charteris-Black 2004: 28), and is used to "persuasively convey evaluations and constitutes a potentially ideological property of texts" (Sacristan 2005: 221). Political metaphor emerges from both the physical as well as social context in which it is produced and it cannot be interpreted without the reference to personal background of discourse participants and both historical as well as situational context of use, i.e. meso- and macro-levels in Fairclough's classification. ${ }^{6}$

Chilton (2004) argues that language and political behaviour should not be merely seen as instances of social practices. On the contrary, because both are fundamentally based on cognitive traits of the human mind, political discourse should be primarily understood and examined as "necessarily a product of individual and collective mental processes" (Chilton 2004: 51). Adopting a cognitive viewpoint, Chilton considers metaphor an essential part of these processes, most of which are situated beyond the area of informed voter control.

\section{Conceptual metaphor and its processing}

Metaphor, as a phenomenon, involves both conceptual mappings and individual linguistic expressions. However, the two must be kept distinct: "the locus of metaphor is not in the words themselves, but in our mental images and in the way we conceptualize one mental domain in terms of another" (Lakoff 1993: 203). Metaphor theorists commonly use the term 'metaphor' to refer to conceptual mapping, and the term 'metaphorical expression' to refer to the individual linguistic expression (word, phrase, or sentence) that is sanctioned by this mapping (which is what the word 'metaphor' referred to in traditional theories that regarded metaphors as artistic and very often deviant linguistic expressions whose meaning, if any, is reducible to some set of literal propositions). More technically, metaphor can be understood as a "cross-domain mapping in the conceptual system" (Lakoff 1993: 203) which basically "has three parts: first, a fixed conceptual

\footnotetext{
5 Fairclough distinguishes "three-dimension framework of studying discourse": micro-level (at which "aspects of linguistic analysis are considered, as well as the use of metaphors and rhetorical devices"); meso-level (at which "aspects such as author of a text and its target audience" are considered); macrolevel (at which "intertextual and interdiscursive elements, along with societal currents affect the given text”) (1995: 51) (quoted after Barry et al. 2006).

6 Personally, I am convinced that conceptual metaphor is a linking device between all of the three levels of analysis.
} 
domain that is the source; second, a fixed conceptual domain that is the target; and third, a fixed metaphoric mapping at the conceptual level of entities, relations, knowledge, reasoning patterns, image-schemas, and schematic structure from the source to the target" (Turner 1991: 158). In the CMT model, metaphorical mapping is primary to language, which is secondary. The enormous productivity of metaphorical conceptualisation results from the unique ability of metaphor to carry over details of extensive knowledge from the source domain to the target domain. ${ }^{7}$ This knowledge is not only carried over to the target, but metaphoric mapping is also a means of shaping our comprehension of the target, which is probably the most important reason why metaphors are such valuable devices in political communication. According to Lakoff (2009), political debates are metaphorical competitions or even "wars on metaphors" which become routine forms of communication (both spoken and written) totally acceptable to a broader audience who more often than not accepts the role of a passive witness.

In his more recent politically focused publications, Lakoff defines conceptual metaphors as "frame-to-frame mappings across conceptual domains" and linguistic metaphors as "surface reflections of those conceptual mappings" (Lakoff 2012: 776). Lakoff primarily focuses on the effects of linguistic metaphors on individuals' attitudes and behaviour by means of metaphorical framing understood as "selecting some aspects of a perceived reality and making them more salient in a communication text, in such a way as to promote a particular problem definition, causal interpretation, moral evaluation, and/or treatment recommendation for the item described" (Entman 1993: 52). ${ }^{8}$ By shaping the inferences that people make about the domains described with the help of metaphorical frames, metaphors help to organise complex information.

Framing effects of metaphor is not a marginal issue and as such should not be overlooked as a phenomenon. However, because of space limitations, let me provide the most concise account of this complex issue which obviously deserves a more serious examination. For instance, Musolff promotes the view of framing as "establishing a particular set of frames as the dominant one in the public political debate, thus setting its agenda as well as target topics and values, and influencing its outcome" (Musolff 2019: 3). Musolff argues that an account of framing in its "emphatic sense," as advocated

\footnotetext{
7 Lakoff refers to such "carryovers" as metaphorical entailments, which are "part of our conceptual system" (Lakoff 1987: 384) and divides them into two types: ontological and epistemic. Ontological entailments result from fixed ontological correspondences, which means that entities in the target domain have systematic correspondences in the source domain. Epistemic entailments are a result of "correspondences between knowledge about the source domain and corresponding knowledge about the target domain” (Lakoff 1987: 385).

8 The issue of metaphorical framing turns up already in Metaphors We Live By when the authors write: "Political and economic ideologies are framed in metaphorical terms. (...) A metaphor in a political or economic system, by virtue of what it hides, can lead to human degradation" (Lakoff \& Johnson 1980 [2008]: 236).
} 
by Lakoff, "is aimed at performing a twofold task: first, to identify and describe the existing frames for a target topic, including the emergence of a new frame and second, to diachronically analyse their discursive development through semantic-pragmatic exploitation and contestation so as to demonstrate the possible dominance of one frame or a set of frames over others" (Musolff 2019: 3). It is most important to realise that metaphorical structuring is usually partial, not total: in most cases only a part of the metaphorical concept involved fits the whole mapping. This happens because the role of particular mappings is to highlight certain aspects of concepts and hide others.

In reference to metaphor recognition, Gibbs observes that "people often comprehend and interpret metaphors without having to recognize, either consciously and unconsciously, that an expression is of a certain type (e.g. that it is a metaphor, as opposed to a literal statement)" (1992: 577). Many metaphors, which very often "resonate with latent symbolic representations residing at the unconscious level" (Mio 1997: 130), might appear invisible because we understand them straight away and effortlessly and their metaphorical character usually goes unnoticed. Mio further argues that people "comprehend or even recognize a metaphor without making any assessment of its aptness (i.e. its appreciation)" (1997: 130). ${ }^{9}$ However, this view is not universal. Steen observes that in "the original thesis of cognitive linguistics, (metaphor was viewed as) a matter of backstage cognition, automatically but unconsciously utilizing entrenched cross-domain mappings which have been acquired during people's cognitive and linguistic development" (2011:59)..$^{10}$ Far from it, Steen claims that "metaphor may manifest itself in communication when it is used deliberately, and then it is a matter of conscious thought by challengeable metaphorical models with a predominantly social function, as an official, contested, implicit or emerging metaphorical representation of some aspect of the world” (2011: 59).

Essentially, processing metaphor has to do with the system of inferences that discourse participants (more or less) habitually implement to determine what conceptual metaphors indicate about the target domain. Maalej argues that in its varied manifestations, discourse guides us to old and new conceptual metaphors and "linguistic metaphors that trigger old conceptual metaphors are of the conventional kind, and do not require a lot of cognitive processing" (Maalej 2007: 137). In different circumstances, more immediate, local contexts can very often prime the use of particular novel metaphors (see e.g., Boroditsky 2001; Gibbs 2006; Steen 2011; Steen et al. 2017). As with entrenchment, mutual

\footnotetext{
9 A metaphorical expression can be perceived as apt or not, depending on the quality of the cross-domain mapping (for a more detailed analysis of the issue of aptness see e.g., Steen et al. 2017: 2865).

10 The most conventionalised connections are represented by primary metaphors such as AFFECTION IS WARMTH, IMPORTANT IS BIG, HAPPY IS UP, INTIMACY IS CLOSENESS, BAD IS STINKY, DIFFICULTIES ARE BURDENS, MORE IS UP, CATEGORIES ARE CONTAINERS, SIMILARITY IS CLOSENESS, LINEAR SCALES ARE PATHS, etc. (for details see Grady 1997; Lakoff \& Johnson 1999).
} 
coherence, productivity, and other aspects, metaphorical conventionality is a matter of degree. Kövecses calls the most conventional and deeply entrenched metaphors clichés (Kövecses 2002: 30). In reference to Polish discourse of politics, metaphorical clichés typically use sports, games, war, theatre, transport, furniture, and cooking as source domains for mappings (see e.g., Burzyński 2013). Some of them are so de-lexicalised that they already have the role and status of terms found in official studies, e.g., scena polityczna, dziura budzetowa, zaciskanie pasa (Eng. the political scene, a budget hole, belt-tightening).

Steen et al. argue that "(w)hen a specific concept is repeatedly used figuratively, people become familiar with the intended meaning of the metaphor, and the metaphor becomes conventional" (2017: 2862). ${ }^{11}$ The investigators acknowledge the positive influence of conventional metaphors on message comprehension and they argue that conventional mappings "make a text more concrete, clear, and easy to understand" (Steen et al. 2017: 2863). On the other hand, Steen and colleagues admit that because "recipients enjoy it when a message allows them a new insight into something familiar" (Steen et al. 2017: 2862), novel metaphors have more potential to increase attractiveness and imaginativeness of the message. Due to the underlying mechanism of "affective text perception," novel metaphors can affect people's issue viewpoints and thus positively influence affective responses to a communicated message (Steen et al. 2017).

\section{Critical Metaphor Analysis}

Traditionally, most research in cognitive linguistics went on to argue that metaphorical conceptualisation arises to a significant extent, from recurring aspects of embodied experience (Johnson 1987; Gibbs 1997; Lakoff \& Johnson 1999). People systematically characterise abstract ideas, thoughts, religious beliefs, political and ethical situations in terms of bodily movements, functions and experiences. Any recurrent pattern of experience is describable by means of image schemata, i.e. embodied prelinguistic structures of experience. Johnson's (1987) and Lakoff's (1987) analyses of the role of image schemata in cognition and language showed the ways in which the aspects of experience formed at the preconceptual level organise every dimension of our reasoning and understanding. Out of the basic bodily interactions, our schematic senses of object, balance, force, cycle, etc. become extended and modified. It is out of these basic cognitive tools that more complex cognitive models of reality are constructed. ${ }^{12}$

11 Consistent with the premises of the Career of Metaphor Theory (Bowdle \& Gentner 2005), a shift in the mode of processing takes place when metaphors become conventionalised: novel metaphors are processed via comparison and conventional metaphors are processed by means of categorisation.

12 As a consequence, the main constraint of metaphoric conceptualisation, namely the Invariance Principle, emphasised the role of image schemata (Turner 1990: 254). 
And more recently, apart from addressing other points of controversy, metaphor researchers (e.g. Kövecses 2015, 2017; Rakova 2002) have cast doubt on the underlying issue of the embodied mind approach as emphasising the role of universal bodily experience instead of the interaction of body and context and their relationship to culture. Kövecses (2017) sees context as a priming device in the production and comprehension of metaphors in discourse, where priming is understood as a phenomenon in which exposure to a stimulus, such as a word or image, influences the response to a subsequent, related stimulus. ${ }^{13}$ According to Kövecses (2017: 19), priming is based on the simulation of some experience in the following contexts: situational, discourse, bodily, and conceptual-cognitive. All four of these context types can be broken down into various kinds of specific contextual factors (for details see Kövecses 2015). "The metaphors based on the situational, the discourse, the conceptual-cognitive context, together with the bodily one that involves unique features of individual bodies may represent the majority of cases of metaphor use in natural communicative situations” (Kövecses 2017: 26).

Discourse metaphors are context-related verbal expressions containing a construction that evokes an analogy negotiated in the discourse community. Actually, in-depth studies of metaphors in discourse show that their use and comprehension are influenced by a large variety of contextual factors (Fairclough 1995; Barnden 2009; Charteris-Black 2004; Leezenberg 2001). Van Dijk proposes the idea that contextual content is represented by the conceptualisers as a "context model," i.e. "a cognitive model of the situation in which such communication takes place that comprises a number of components, including the following: Setting (time, location, circumstances, props) and Happening, which consists of Actors (individuals or groups) and Activity/ Conduct” (Van Dijk 2009:39). Critical Metaphor Analysis is a paradigm that basically brings together mind, discourse, and socio-cultural context. It is defined as an "integration of cognitive, semantic and pragmatic approaches that is based on corpus evidence" (Charteris-Black 2004:13). Allowing for the combination of several characteristics of metaphors such as the cognitive, the rational and the historical, this model does not pose the question of whether we understand metaphor, but rather the question of how we understand it within an authentic context of use. Consistent with Fairclough's pattern of analysis, summarized by Liu \& Guo (2016: 1078) as a combination of "whatness," "howness," and "whyness," CMA attempts to: "identify which metaphors are chosen and to explain why these metaphors are chosen by illustrating how they create political myths (in addition to indicating) how the metaphors of one social or political group may be taken over, exploited and developed by those of another for competing ideological ends" (Charteris-Black 2004: 28-9).

13 Within social psychology, this process has specifically come to be defined in terms of how events or actions influence the activation of stored knowledge (Higgins \& Eitam 2014). 
The model consists of three steps: description, interpretation, and explanation, which are argued "to work in a complementary fashion, with each step motivating the next one" (Maalej 2007: 152). Technically, at the description stage the metaphor analyst "seeks to discover a potential frame, explicit or implicit, to which metaphoric processing and/or processing metaphor are applied in view of writing the conceptual metaphors behind discourse" (Maalej 2007: 152). Interpretation consists of spelling out the elements of the mapping (involving two types of governing correspondences: ontological and epistemic) and making the necessary inferences that constitute a system of entailments. As a cognitive-pragmatic step, explanation "is captured through two pragmatic functions of metaphor, namely, evaluation and persuasion, which relate the conceptual, individual part of the mind to its shared, social one - or social/cultural cognition" (Maalej 2007: 149). At this stage, in all probability the most interesting aspect for a critical analyst, is that the main intentions and objectives of political actors are explained. A fundamental question is: what intent drives a political actor to use a particular metaphor to describe a certain political state of affairs or reach a well-planned goal? The CMA approach most usefully takes into consideration the issue of intentionality as ingrained in the use of metaphors in political communication.

Politicians deliberately use different discursive tools to foster the processes of othering and polarisation. Van Dijk (1998, 2009) defines ideologies as the underlying social beliefs and values that form the basis of the organization and control of social representations shared by members of a group, including representations of the self and others. One of the fundamental underpinnings of such ideologies is the delimitation of 'us' and 'them' in the form of the ingroup-outgroup polarisation which serves to self-represent the ingroup, organise its social practices and promote the interests of its members with respect to other social groups (see van Dijk 2011). Van Dijk (2011: 396) argues that one of the most common strategies of "ideological control in discourse" is the well-known and widely-applied ideological square. The principles of metaphor use follow the overall goals of positive self-presentation and negative other-presentation that we can observe in the ideological square. That is, we, our people and our actions and properties tend to be described in metaphorical meanings that derive from conceptual fields with positive associations; whereas the opposite is true for the description of our political opponents or enemies. Within the overall strategy of positive self-presentation and negative otherpresentation, we may thus expect that the two groups are characterised by reversed values, where the opposition is always the embodiment of evil, referred to in Polish media as e.g., trup polityczny, bankrut polityczny, talibowie (corresponding in English to political corpse, political bankrupt, the Taliban), while the other side is always characterised as e.g., aniot pokoju, partia Boga, matka sukcesu (an angel of peace, God's party, the mother of success), etc. Essentially, as many political metaphor researchers demonstrate 
(e.g., Charteris-Black 2004; Lakoff 2009; Van Teeffelen 1994), the power of metaphors in the field of politics lies in its prowess to stress certain details and connections while simultaneously minimising others.

\section{Critical analysis of the wrestling with a pig in the mud metaphor in its political context}

In the 2019 European Parliament election in Poland, from the very beginning only two committees had a realistic chance of winning: Law and Justice (Pol. Prawo i Sprawiedliwość) - the ruling party with a conservative-populist profile, and European Coalition (Pol. Koalicja Europejska) - a pro-democratic coalition consisting of five opposition parties that openly support the processes of Westernisation and secularisation coming from the West. In such a context, there arose questions both about the political commitment of the Polish Catholic Church and about the instrumental use of the Church by the political right.

As indicated by the number of baptised Catholics (86\%) and self-declared regular church-goers (38\%), Poland is one of the most Catholic countries in the world (Rozkrut et al. 2018: 114). In 1998 the Vatican-Poland concordat was ratified. Due to the role of the Catholic Church in the complicated history of the country, especially during the 123-year-long period of partition and in the post-1945 communist era, Catholicism is still an important component of national identity. The Catholic ethical code and values are respected by the majority of self-declared Catholics, who hold rigid views about social topics such as LGBT rights, abortion, euthanasia, in vitro fertilisation, traditional families, mass migration from Muslim countries, and so on. What is really happening in the brains of Poles is that there are two fundamentally different modes of perception of those sensitive issues; one fundamentally progressive, the other fundamentally conservative, to use Lakoff's terms (2009). This sharp division, dubbed as the Polish-Poland war (Pol. wojna polsko-polska), is visible and audible throughout the streets of Polish cities and villages, and in people's homes is presented and reinforced by the media.

Three weeks before the European Parliament election, Donald Tusk, the co-founder and ex-chairman of the biggest opposition party: Civic Platform (Pol. Platforma Obywatelska), the Prime Minister of Poland from 2007 to 2014 and currently the President of the European Council, gave a lecture on "Hope and responsibility. On Constitution, Europe and Free Elections" at the Auditorium Maximum of the University of Warsaw. However, it was not Tusk's methodical presentation that became one of the most widely commented on political events of 2019 in Poland. Moments before Tusk's address, one of the organisers of the meeting, Leszek Jażdżewski, delivered his 10-minute support speech. Jażdżewski is the editor-in-chief of Liberté!, a member of the Association of Journalists and an expert on international politics. In reality, Tusk's lecture which had 
been billed as the main point on the agenda, was given little, if any, media attention in comparison to the enormous interest triggered by Jażdżewski's introductory presentation. In his politically and ideologically committed manifesto Jażdżewski, who is an involved political activist, strongly attacked, among others, the Catholic Church. The journalist referred to sexual and financial scandals involving priests, saying among other things, that nowadays the society should not look for moral values in the Church, claiming that if Christ were to be alive at the present time in Poland he "would most likely be crucified by those who use the cross as a stick to drive the humble sheep into the pen." Essentially, metaphorical expressions permeated and dominated the whole speech and constituted the discursive backbone of its argumentative structure. However, the example which deserves special attention of both a political commentator and of a linguist is the wrestling with a pig in the mud (Pol. zapasy ze swinia $w$ błocie) metaphor, which was most probably aimed at providing an effective punch line to Jażdżewski's speech as well as ultimately paving the dedicated liberal's way to his own political rank and success. After the speech, this metaphor was vividly discussed by the media and other political actors (as well as by the broader public), which within a couple of weeks turned Jażdżewski into a political media celebrity.

The persuasive goal of the liberal speaker was to emphasise the immorality and bad nature of the conservative Catholic Church in Poland. Jażdżewski based his argumentation on the common tendency to metaphorically project the attributes of animals onto different types of organisations and currently held values in human society. He used the novel expression which framed the Catholic Church as a ruthless, greedy animal; namely, a pig. The metaphor, which is far more entrenched in English and part of commonplace public communication in this language, has scarce tradition of use in Polish linguistic culture. Actually, the foremost national corpus of Polish (Narodowy Korpus Języka Polskiego) mentions its use only once. Wrestling with a pig in the mud is an example of a situation when a certain image - the image of a human fighting with a pig in the mud, and consequently its image-schematic structure - is part of the mapping. ${ }^{14}$

Generally, image metaphors map only one image onto one other image. What an image metaphor really offers language users is the possibility of mapping some of the very rich imagistic detail of the image. It is the proliferation of detail in the images that limits image mappings to highly specific cases and makes them "one-shot" mappings (Lakoff 1993: 229). Apparently, image metaphors in comparison to structural metaphors may lack rich inferential structure. However, as Lakoff \& Turner (1989: 8, 92) observe, image metaphors can trigger structural-conceptual metaphors. In fact, metaphor is capable of building up meaning all the way from the most basic levels to the most sophisticated

14 Invariance is also present as the basic image schemata activated by this multifaceted mapping are object, contact and counterforce. 
and creative ones (see Lakoff \& Turner 1989; Grady 1997). As a consequence, metaphorical expressions are not expressions of isolated meanings, but they represent particular levels of a hierarchical organization, in which the mappings at the lower level of the hierarchy inherit the structure of the mappings at the higher level. ${ }^{15}$ In 'Doing CDA with the Contemporary Theory of Metaphor' Maalej refers to Gibbs's (1994: 117) claim that a rich set of entailments can be drawn from any metaphor. Some entailments may be specifically intended by the speaker or author of the metaphor, while other ones might be unauthorised but still understood as being reasonable (Maalej 2007: 147). Actually, "[w] e can invent new metaphors by figuring out the image-schematic structure of the target and finding a source that matches it" (Turner 1991: 174). In the case of the wrestling with a pig in the mud metaphor, the planned persuasive effect results from what CharterisBlack (2004: 35) calls "a tension between a literal source domain and a metaphoric target domain." How can wrestling a pig in the mud be used in the sense of debating with the Catholic Church? This is obviously accomplished via a system of metaphorical correspondences and their entailments. Essentially, it is an example of a composite metaphor in which we deal with hierarchical organisation of interplaying structures. The image metaphor stimulates activation of higher-level mappings, namely basic-level structural metaphors THE CATHOLIC CHURCH IS A PIG, (a subcategory of PEOPLE ARE ANIMALS and THE INSTITUTION IS AN ORGANISM), ARGUMENT IS WAR, and IMMORALITY IS DIRT. ${ }^{16}$

In accordance with the Contemporary Metaphor Theory, in the case of the basic conceptual metaphor THE CATHOLIC CHURCH IS A PIG, the source is our concept of PIG and the target is our understanding of CHURCH in terms of PIG. The metaphoric mapping connects our concept of PIG to our understanding of CHURCH in terms of PIG. Through the metaphor PEOPLE ARE ANIMALS, attributed animal behaviour is mapped onto human behaviour: we can infer that the Catholic Church is selfish, insatiable, and as thoughtless as pigs are thought to be. Actually, we cannot neglect the range of inferences provided by two generic-level metaphors, viz. the GENERIC IS SPECIFIC and the Great Chain of Being (for details see Lakoff \& Turner 1989: 166-168; Turner 1991: 167-169; and especially Krzeszowski 1997: 64-74). The inferences are done by mapping attributes and behaviour characteristic of one level - animals, represented by a specific-level instantiation (a pig), onto attributes and behaviour at another level - humans (in this particular case the high-ranking members of the Catholic Church clergy). What is crucial in the structure

15 Metaphors higher up in the hierarchy, e.g. The Great Chain of Being (GCB), The Event Structure, or generic is specific, tend to be more widespread than mappings representing lower levels. Gibbs claims that the Event Structure and similar metaphors are universal, while metaphors at lower levels are more culturally restricted (Gibbs 1994:154).

16 The idea that simple metaphors interact to yield more elaborate conceptualisations has been discussed by researchers working in the CMT framework (especially see Lakoff and Turner's 1989 discussion of 'composite' metaphors, and Grady's 1997 explicit analysis of the "unification” or "binding” of metaphors). 
of the Great Chain of Being is the fact that different forms of being are characterised by their highest level of attribute. In wrestling with a pig in the mud the correspondence on which we base the projection between the Catholic Church and a pig is the highest level of attribute of animals - their instinctual nature, which makes their behaviour primitive and ruthless in their struggle for survival. The mapping highlights competitiveness and aggression as features shared by humans and animals. More specifically, the rulers of the religious institution, whose beliefs are formulaically fortified against any self-doubt, are seen as acting according to the behavioural traits ascribed to a thoughtless pig. It is important to note that the particular analysed projection is unidirectional and asymmetric. Goaty (2006: 34) observes that the most common animal metaphors for humans are pejorative, suggesting that it is desirable to distance ourselves from animals, both conceptually and emotionally. The researcher mentions some naturalist theories that emphasise symbiosis and cooperation between humans and animals and claim that it is natural and right to behave as animals do. Yet, Goaty stresses that most sociobiological approaches prove that our differences from animals are what makes us most human and notes the prescriptive character of metaphor patterns that reflect the strong tendency to regard animal behaviour as something for humans to avoid (for details see Goaty 2006). Actually, what Jażdżewski wanted to attain by comparing a disliked and corrupt institution to a disgusting, selfish, and insensitive pig was to reduce the Catholic Church's rank in the hierarchy of beings, rather than to elevate the pig's position to the higher level occupied by humans or institutions.

Following Lakoff \& Johnson's idea that "argument is partially structured, understood, performed, and talked about in terms of war" (1980: 4-5), everyday language automatically applies warlike vocabulary such as fight, battle, struggle, defeat, survive, attack, win, etc. to any confrontational situation. Still, it is political discourse that makes remarkably ample use of the deeply entrenched and thoroughly described ARGUMENT IS WAR metaphor (see e.g., Ling 2010). Conflicts between politicians are often understood as a physical confrontation in a battlefield and politicians are seen as fighters. In particular, election debates are framed as duels between the candidates who apply different strategies and use different types of weaponry against their opponents. Jażdżewski's example also fits into this model. It takes advantage of elements such as the physical contact between the fighters, battlefield and weaponry. The Catholic Church as a pig and the opposition as its human opponent are FIGHTERS who struggle in the field of mud, namely the contemporary Polish political arena, understood here as a type of BATTLEFIELD. In the case of Jażdżewski's example, not logically justified arguments, but invectives are WEAPONS used to humiliate and defeat the opponent. Literally, only the human participant has access to this sort of arms, as a pig is incapable of speaking. However, it has an extra weapon at its disposal, namely cloven hooves, which give it excellent traction. Wrestling with the pig is a sort of fierce competition in which the human participant 
is given no time to think and realise his tactics. The receiver of Jażdżewski's speech should easily infer that this sort of battle is utterly useless: it drastically exhausts the opposition and brings no ideological benefits.

Associated with the wrestling with a pig in the mud image metaphor is another basic conceptual structure, namely IMMORALITY IS DIRT and some of the actions that are its further developments, e.g. cleaning, washing. Sherman \& Chlore (2009: 1025) claim that "more than merely a rhetorical device for moral discourse the moral purity metaphor is a deeply embodied phenomenon covertly shaping moral cognition." The embodied symbolism of physical cleansing, which suggests a psychological association between bodily purity and moral purity, manifests itself more than ever in the sphere of religion and religious ceremonies based on the sacred functions of water. Lakoff \& Johnson argue that the link between cleanliness and the prescribed and widely accepted moral standards can be explained by the fact that "morality is fundamentally seen as the enhancing of well-being, especially of others" (1999: 291). Actually, two most prominent target domains structured by the concepts pertaining to physical cleanliness are morality and sexuality (see e.g., Deignan 1997). The parallels established between the cleanliness of the body and moral purity are used to construct a major pair of oppositions: MORALITY IS PURITY and IMMORALITY IS DIRT, which share the common entailment PURIFYING IS CLEANSING. MORALITY IS PURITY is related to PURITY IS CLEANLINESS (for details see Lakoff \& Johnson 1999: 307). Lizardo (2012: 380) observes that apart from the fields of sports and war, the conceptualisation of IMMORALITY AS DIRT is also prominent in the sphere of politics, the participants of which are prone to break moral principles in order to achieve the specific goals they aspire towards. In Polish political discourse, frequent collocations of cleanliness, e.g., czyste sumienie, czyste intencje, czyste ręce (literally a clean conscience, clean intentions, clean hands) reveal association of cleanliness with decent moral behaviour and are overly positive, while the connection between immoral conduct and dirt is expressed by explicitly negative expressions such as brudna robota, brudny interes, brudne ręce (dirty work, dirty business, dirty hands).

The metaphorical structure guides the recipients' moral judgment - the Catholic Church is highly immoral: instead of remaining pure and unblemished it is smeared with mud. At this point of the interpretation there is still a chance for improvement, as dirty items can be washed in order to bring them back to their previous state of cleanliness. Lakoff \& Johnson (1999: 308) argue that "the question of moral rehabilitation amounts to the question of whether it is possible to clean up one's act and restore purity of will." However, it is doubtful whether Catholic authorities are able and willing to clean their moral dirt, if it is washable at all. Definitely, the metaphorical pig does not want it because it gains a lot of pleasure from brawling in the mud and especially from making itself dirty. In that sense it is anything but unemotional. 
What is most important, is that the persuasive impact of Jażdżewski's metaphor does not result from its conceptual content alone. Actually, it is the emotional force of the wrestling with a pig in the mud that makes it value-laden and ideologically determined. Conventional mappings enable political actors to convey certain easily digestible ideas, which certainly play an important role in the ideological assimilation of a given metaphor. On the other hand, if a new frame is easy enough to catch on, due to the psychological effect of priority and freshness, it may be better remembered by a target voter. In a broader perspective, by selecting such an emotion-laden novel example, Jażdżewski hoped to provoke and activate his audience. He wanted the metaphorical spectators watching the scene of wrestling with a pig in the mud to identify with the better, human side of the conflict, and eventually manifest their identification at the ballot box.

\section{Conclusion}

As vehicles of covert messages, metaphors are used by political actors with precise strategic aims. By letting us conceive complex social issues in terms of commonplace entities, events and activities, they make politics less abstract and more tangible to a broader audience. Essentially, they are used in order to advance one particular view of the world whilst discrediting other ideologies and belittling political opponents. Especially novel mappings become powerful persuasive tools used to support political campaigns. The wrestling with a pig the mud example was deliberately chosen by Leszek Jażdżewski in order to fan the flames of political conflict rather than seek consensus-based solutions and in this way activate political participation. It is the critical analyst's role to equip the recipients of discourse with the realisation that far from being spontaneous, the use of metaphoric expressions is meticulously planned by politicians.

The role of framing effects of deliberately chosen political metaphors requires and undoubtedly deserves serious examination. Though the knotty issue, just hinted at, would have to transcend by far the scope of the present analysis, the challenge is probably worth attention and effort, as some further research might reveal the existence of an interesting mechanism capable of giving new insight into the nature of conceptual metaphor.

\section{References}

Barden, J. 2009. Metaphor and context: A perspective from Artificial Intelligence. In: A. Musolff \& J. Zinken (eds.), Metaphor and Discourse, 79-94. London: Palgrave.

Barry, D., Carroll, B. \& Hansen, H. 2006. To text or context? Endotextual, exotextual, and multi-textual approaches to narrative and discursive organizational studies. Organization Studies 27(8): 1091-1110.

Boroditsky, L. 2001. Does language shape thought? Mandarin and English speakers' conceptions of time. Cognitive Psychology 43(1): 1-22. 
Bowdle, B. F. \& Gentner, D. 2005. The career of metaphor. Psychological Review 112(1): 193-216.

Bischoping, K. \& Gazso, A. 2016. Analyzing Talk in the Social Sciences: Narrative, Conversation and Discourse Strategies. Thousand Oaks, CA: Sage Press.

Burzyński, R. 2013. Metafory jako narzędzie polityki i oddziaływania politycznego. Unpublished Ph.D. Dissertation. Warsaw University.

Chilton, P. 2004. Analysing Political Discourse: Theory and Practice. London: Routledge.

Charteris-Black, J. 2004. Corpus Approaches to Critical Metaphor Analysis. Basingstoke: Palgrave Macmillan.

Charteris-Black, J. 2005. Politicians and Rhetoric - The Persuasive Power of Metaphor. Basingstoke: Palgrave Macmillan.

Cottle, S. 2000. Introduction. Media research and ethnic minorities: Mapping the field. In: S. Cottle (ed.), Ethnic Minorities and the Media: Changing Cultural Boundaries, 1-30. Buckingham: Open University Press..

Coxall, B., Robins, L. \& Leach, R. 2003. Contemporary British Politics. London: Palgrave.

Deignan, A. 1997. Metaphors of desire. In: K. Harvey \& C. Shalom (eds.), Language and Desire, 21-42. London: Routledge.

Entman, R. M. 1993. Framing: Toward clarification of a fractured paradigm. Journal of Communication 43(4): 51-58.

Foucault, M. 1969. L’Archéologie du savoir. Paris: Éditions Gallimard.

Fairclough, N. 1989. Language and Power. London: Longman.

Fairclough, N. 1995. Critical Discourse Analysis: The Critical Study of Language. London: Longman.

Gibbs, R. W. 1992. Categorization and metaphor understanding. Psychological Review 99: 572-577.

Gibbs, R. W. 1994. The Poetics of Mind: Figurative Thought, Language and Understanding. Cambridge: Cambridge University Press.

Gibbs, R. W. 1997. How language reflects the embodied nature of creative cognition. In: T. B. Ward, S. M. Smith \& J. Vaid (eds.), Creative Thought: An Investigation of Conceptual Structures and Processes, 351-373. Washington, DC: American Psychological Association.

Gibbs, R. W. 2006. Metaphor interpretation as embodied simulation. Mind and Language 21(3): 434-458.

Goaty, A. 2006. Humans, animals, and metaphors. Society and Animals 14(1):15-37.

Grady, J. E. 1997. Foundations of Meaning: Primary Metaphors and Primary Scenes. Berkeley: University of California Press. Unpublished Ph.D. Dissertation.

Higgins, E. Tory \& Eitam, B. 2014. Priming ... shmiming: It's about knowing when and why stimulated memory representations become active. Social Cognition 32: 97-114. 
Johnson, M. 1987. The Body in the Mind: The Bodily Basis of Meaning, Imagination, and Reason. Chicago: University of Chicago Press.

Kövecses, Z. 2002. Metaphor: A Practical Introduction. Oxford: Oxford University Press.

Kövecses, Z. 2015. Where Metaphors Come From: Reconsidering Context in Metaphor. Oxford: Oxford University Press.

Kövecses, Z. 2017. Conceptual metaphor theory: Some new proposals. LaMiCuS 1 (1): 16-32.

Kress, G. \& van Leeuwen, T. 2001. Multimodal Discourse: The Modes and Media of Contemporary Communication. Oxford: Oxford University Press.

Krzeszowski, T. P. 1997. Angels and Devils in Hell. Elements of Axiology in Semantics. Warsaw: Energeia.

Lakoff, G. 1987. Women, Fire, and Dangerous Things: What Categories Reveal about the Mind. Chicago/London: University of Chicago Press.

Lakoff, G. 1993. The contemporary theory of metaphor. In: A. Orthony (ed.), Metaphor and Thought, 202-251. Cambridge: Cambridge University Press.

Lakoff, G. 2009 The Political Mind: A Cognitive Scientist's Guide to Your Brain and Its Politics. New York: Penguin.

Lakoff, G. 2012. Explaining embodied cognition results. Topics in Cognitive Science 4: 773785.

Lakoff, G. \& Johnson, M. 1980 [2008]. Metaphors We Live By. Chicago: University of Chicago Press.

Lakoff, G. \& Johnson, M. 1999. Philosophy in the Flesh. The Embodied Mind and its Challenge to Western Thought. New York: Basic Books.

Lakoff, G. \& Turner, M. 1989. More than Cool Reason: A Field Guide to Poetic Metaphor. Chicago: University of Chicago Press.

Leezenberg, M. 2001. Contexts of Metaphor. Amsterdam/London: Elsevier.

Liebes, T. \& Ribak, R. 1991. A mother's battle against TV news: A case study of political socialization. Discourse and Society 2(2): 203-222.

Ling, S. 2010. A Cognitive study of war metaphors in five main areas of everyday English: Politics, business, sport, disease and love. (Retrieved from http://www.diva-portal. org/smash/get/diva2:397473/FULLTEXTO1.pdf)

Lizardo, O. 2012. The conceptual bases of metaphors of dirt and cleanliness in moral and non-moral reasoning. Cognitive Linguistics 23(2): 367-393.

Liu, K. \& Guo, F. 2016. A review on Critical Discourse Analysis. Theory and Practice in Language Studies 6(5): 1076-1084.

Maalej, Z. 2007. Doing critical discourse analysis with the contemporary theory of metaphor: Towards a discourse model of metaphor. In: C. Hart \& D. Lukeš (eds.), Cognitive Linguistics in Critical Discourse Studies: Application and Theory, 132-158. Cambridge: Cambridge Scholars Press.

Mio, J. S. 1997. Metaphor and politics. Metaphor and Symbol 12(2): 113-33. 
Musolff, A. 2004. Metaphor and Political Discourse. Analogical Reasoning in Debates about Europe. London: Palgrave Macmillan.

Musolff, A. 2010. Metaphor, Nation, and the Holocaust: The Concept of the Body Politic. New York: Routledge.

Musolff, A. 2014. Metaphorical parasites and "parasitic" metaphors. Semantic exchanges between political and scientific vocabularies. Journal of Language and Politics 13(2): 218-233.

Musolff, A. 2019. Metaphor framing in political discourse. Mythos-Magazine. Politisches Framing 1: 1-10.

Perrez, J., Reuchamps, M. \& Thibodeau, P. H. (eds.). 2019. Variation in Political Metaphor. Amsterdam: John Benjamins.

Potter, J. \& Wetherell, M. 1987. Discourse and Social Psychology: Beyond Attitudes and Behaviour. London: Sage.

Rakova, M. 2002. The philosophy of embodied realism: A high price to pay? Cognitive Linguistics 13: 215-244.

Rozkrut, D. et al. Maty Rocznik Statystyczny Polski 2018 (Concise Statistical Yearbook of Poland 2018). Warsaw: GUS.

Sacristan, M. V. 2005. A critical cognitive-pragmatic approach to advertising gender metaphors. Intercultural Pragmatics 2(3): 219-252.

Semino, E. 2008. Metaphor in Discourse. Cambridge: Cambridge University Press.

Sherman, G. D. \& Chlore, G. L. 2009. The color of sin. White and black are perceptual symbols of moral purity and pollution. Psychological Science 20(8): 1019-1025.

Steen, G. 2004. Can discourse properties of metaphor affect metaphor recognition. Journal of Pragmatics 36. 1295-1313.

Steen, G. 2011. The contemporary theory of metaphor - now new and improved! Review of Cognitive Linguistics 9(1): 26-64.

Steen, G., Boeynaems, A., Burgers, C. \& Konijn, E. A. 2017. Impact of conventional and novel metaphors in news on issue viewpoint. International Journal of Communication 11: 2861-2879.

Turner, M. 1990. Aspects of the Invariance Hypothesis. Cognitive Linguistics 1(2). 247-255.

Turner, M. 1991. Reading Minds: The Study of English in the Age of Cognitive Science. Princeton: Princeton University Press.

Tyson, L. 1999. Critical Theory Today: A User-Friendly Guide. New York/London: Garland Publishing.

Van Dijk, T. 1988. News Analysis. Case Studies of International and National News in the Press. New Jersey: Lawrence Erlbaum Associates.

Van Dijk, T. 1995. Power and the news media. In D. Paletz (ed.), Political Communication and Action, 9-36. New York: Hampton Press. 
Van Dijk, T. 1996. Discourse, power and access. In: C. R. Caldas-Coulthard \& M.Coulthard (eds.). Texts and Practices. Readings in Critical Discourse Analysis, 84-104. London: Routledge.

Van Dijk, T. 1997. What is political discourse analysis? Belgian Journal of Linguistics 11: 11-52.

Van Dijk, T. 1998. Ideology: A Multidisciplinary Approach. London: Sage.

Van Dijk, T. 2001. Multidisciplinary CDA: A plea for diversity. In: R. Wodak \& M. Meyer (eds.), Methods of Critical Discourse Analysis, 95-120. London: Sage Publications.

Van Dijk, T. 2009. Society and Discourse: How Social Contexts Influence Text and Talk. Cambridge: Cambridge University Press.

Van Dijk, T. 2011. Discourse and ideology. In: T. van Dijk (ed.), Discourse Studies. A Multidisplinary Introduction, 379-407. London: Sage.

Van Gorp, B. 2007. The constructionist approach to framing: Bringing culture back in. Journal of Communication 57(1): 60-78.

Van Leeuwen, T. 2015. Multimodality. In: D. Tannen, H. E. Hamilton \& D. Schiffrin (eds.), The Handbook of Discourse Analysis ( ${ }^{\text {nd }}$ edn), 447-461. London: John Wiley and Sons. Van Teeffelen, T. 1994. Racism and metaphor: the Palestinian-Israeli conflict in popular literature. Discourse and Society 5(3): 381-405.

Wilson, John. 2015. Political Discourse. In: D. Tannen, H. E. Hamilton \& D. Schiffrin (eds.), The Handbook of Discourse Analysis (2nd edn), 775-794. London: John Wiley and Sons.

$* * *$

Katarzyna Pawłowska is a lecturer at The Faculty of Philology of The University of Białystok. Her main teaching areas are descriptive grammar of the English language, comparative linguistics and discourse analysis. She obtained her Ph.D. degree in Cognitive Semantics from the University of Warsaw. Her current research is in the area of Critical Discourse Analysis, with particular focus on deliberate usage of conceptual metaphors in political persuasion. 